\title{
Sustainable Reserve Food Garden (SRFG): Development of a Booklet for the Society
}

\author{
$1^{\text {st }}$ Delvi Adri \\ Biology Department \\ Universitas Negeri Malang \\ Malang, Indonesia \\ co-author: delviadri23@gmail.com
}

\author{
$2^{\text {nd }}$ Mimien Henie Irawati \\ Biology Department \\ Universitas Negeri Malang \\ Malang, Indonesia
}

\author{
$3^{\text {rd }}$ Sueb \\ Biology Department \\ Universitas Negeri Malang \\ Malang, Indonesia
}

\begin{abstract}
Sources of reading on Sustainable Reserve Food Garden (SRFG) which is still less become the causes of low environmental knowledge and environmental awareness behavior. Based on this analysis, booklet development on SRFG is used as a source of reading for the society. The research is developmental research using the ADDIE model. The instrument of data collection used is a questionnaire. Research data are qualitative and quantitative. Subjects of this research are a validator of course expert, a validator of media expert, a field practitioner and social responses to the preliminary trial. The result of the research showed that the development of booklet from media expert is $96.6 \%$ (very valid category), the material expert is $97.9 \%$ (very valid category), and field practitioner is $83.3 \%$ (valid category), and the preliminary test is $85.5 \%$ (valid category). Based on the results, it can be concluded that the developed booklet of SRFG is valid and practical so that it can be implemented to the for society.
\end{abstract}

Keywords-Sustainable Reserve Food Garden, booklet, society.

\section{INTRODUCTION}

One of The National Medium -Term Development Plan 2015-2019 is prioritizing sustainability[1]. The goal of creating food security is Indonesia can manage and fulfill the food needs of the nations $[2,3]$, that has a problem in food insecurity $[4,5,6,7]$. Utilization of yard to develop household food is one alternative policy to maintain household food availability [8,9]. Food Resilience Agency (2016) implement the program of Increasing Diversification and Food Security to optimize the utilization of yard through the concept of Sustainable Reserve Food Garden (SRFG) [10]. The objective of this program is to develop the ability of families in an area meets the needs of food and nutrition sustainably, for an independent and prosperous family and society, to achieve food security [11-13].

The Government, especially the Ministry of Agriculture in the development of SRFG has made implementation model of SRFG in every province in Indonesia [14]. The implementation has been carried out at the community level and environment, but the proportion relatively low [14-19]. This resulted make community's environmental knowledge and environmental community behavior low [20].

The media has a significant role in a reconnaissance [21]. Visual media for reconnaissance can improve memory from $14 \%$ to $38 \%$ [22]. The book is a media for publicizing and transforming knowledge or research results, to provide information to the public [23,24]. Booklet became one of the affective media for delivering the message for public $[25,26]$.
This media is an alternative that can be used for reconnaissance because it uses information technology in an effective and efficient at reconnaissance outcomes and processes [27,28]. The purpose of this study is developing booklets for SRFG as a source of reading for the community.

\section{METHOD}

This research is a research and development that adapting stage of the ADDIE model. This research and development model consists of 5 stages: analyze, design, develop, implement (implement), and evaluate (evaluate). Determination of sample through purposive sampling technique. The subjects of the trial in this study include; (1) a media expert who is a lecturer majoring in Educational Technology, Dr. Henry Preherdhiono, S.Si, M.Pd; (2) a material expert who is a lecturer majoring in Biology in the field of environment teaching at the Graduate University of Malang, Dr. Istamar Syamsuri, M.Pd; (3) field practitioners namely Arga Triyandhana, M.Pd. Respondents in this research are Kenagarian Ampang Kuranji community. The number of respondents is 15 people. The instrument for data collection that used in this research are questionnaires to obtain material expert response data, media experts, environmental practitioners, and community responses. Data were analyzed by using descriptive statistical analysis.

The measurement of the validity used the validity sheets by the experts and the environmental practitioner, and the reliable measurement use questionnaire sheets that are got from the people's response. The formula that is used to analyze the data is as follows.

$\%$ Validity/practicality of the booklet $=\frac{T s e}{T s h} \times 100 \%$ Note:

Tse $=$ empirical total score

Tsh $=$ expected total score

Criteria of the result of the validity/practicality measurement can be seen in Table 1 .

Table 1. Criteria of the result of the validity/practicality measurement

\begin{tabular}{ccl}
\hline $\begin{array}{c}\text { Achievement } \\
\text { level }(\%)\end{array}$ & Category & \multicolumn{1}{c}{ Note } \\
\hline $86-100$ & Very high & Can be used without revision \\
$71-85$ & High & $\begin{array}{l}\text { Can be used, no need to be } \\
\text { revised } \\
\text { May be used with revision }\end{array}$ \\
$56-70$ & Fair & Cannot be used
\end{tabular}




\begin{tabular}{ccc}
$\leq 40$ & Very low & Cannot be used \\
\hline Source of modified [29] & &
\end{tabular}

\section{RESULTS AND DISCUSSION}

The product developed is a booklet of Sustainable Reserve Food Garden (SRFG) for the community. After finishing the media in the development phase, then use the validity measurement to find out the booklet's feasibility and practical measurement of the booklet before it is used and applied in the reconnaissance. The result of measurement invalidity and practicality of booklet obtained by quantitative and qualitative data. The measurement data are described as follows.

\section{The result of the validity booklet}

Validity measurement is used to determine the feasibility of the SRFG booklet before reconnaissance. This validation involves several categories, validation of media experts, material experts, and field practitioners. The measurement data of booklet validity are detailed as follows.

\section{a. Result from Media Expert}

The result from media expert can be seen in Table 2 .

Table 2. The Validation Result from Media Expert

\begin{tabular}{llccc}
\hline No & $\begin{array}{l}\text { Rated } \\
\text { Aspect }\end{array}$ & $\begin{array}{c}\text { Number } \\
\text { of } \\
\text { Aspects }\end{array}$ & $\begin{array}{l}\text { Maximum } \\
\text { Score }\end{array}$ & $\begin{array}{l}\text { Obtained } \\
\text { Score }\end{array}$ \\
\hline 1. & $\begin{array}{l}\text { Cover of the } \\
\text { booklet } \\
\text { design }\end{array}$ & 8 & 32 & $30(93.75 \%)$ \\
$2 . \quad 21$ & 84 & $82(97.6 \%)$ \\
$\begin{array}{c}\text { Content of } \\
\text { the booklet } \\
\text { design }\end{array}$ & & \\
\hline & Obtained score & $\mathbf{1 1 2}$ \\
\hline \multicolumn{2}{l|}{ Maximum Score } & $\mathbf{1 1 6}$ \\
\hline & Qualification Average (\%) & $\mathbf{9 6 . 6}$ \\
\hline & Qualification Average & Very high \\
\hline
\end{tabular}

Based on Table 2 two aspects assessed by expert media validators. Both aspects include booklet cover design and booklet content design. Here's a further explanation of each aspect. The first aspect, booklet cover design. In this aspect, there are eight indicators. In this aspect, two indicators scored three and six indicators scored four. The overall percentage in this aspect is $93.75 \%$, and it is included in the very high feasibility category. The proportions and appearance of the booklet are appropriate for use. The second aspect, design contents of the booklet. In this aspect, there are twenty-one indicators. In this aspect, two indicators scored three and nineteen indicators scored four. This aspect is the percentage of $97.6 \%$ with very high feasibility category. The result of booklet SRGF validity by media expert, it is got percentage of $96.6 \%$ with the properness category very high. It means that the design of the SRGF booklet developed is very proper to be used.

\section{b. The Result of Material Expert Validity}

The result of the validity SRGF booklet by the material expert can be seen in Table 3

Table 3. The Result of Material Expert Validity

\begin{tabular}{|c|c|c|c|c|}
\hline No & $\begin{array}{l}\text { Rated } \\
\text { Aspect }\end{array}$ & $\begin{array}{c}\begin{array}{c}\text { Number } \\
\text { of } \\
\text { Aspects }\end{array} \\
\end{array}$ & $\begin{array}{l}\text { Maximum } \\
\text { Score }\end{array}$ & $\begin{array}{l}\text { Obtained } \\
\text { Score }\end{array}$ \\
\hline 1. & $\begin{array}{l}\text { The cover of } \\
\text { the booklet }\end{array}$ & 3 & 12 & $12(100 \%)$ \\
\hline 2. & Preface & 12 & 48 & $48(100 \%)$ \\
\hline 3. & $\begin{array}{l}\text { Main } \\
\text { material }\end{array}$ & 18 & 72 & $69(95.8 \%)$ \\
\hline & \multicolumn{3}{|c|}{ Obtained score } & 129 \\
\hline & \multicolumn{3}{|c|}{ Maximum Score } & 132 \\
\hline & \multicolumn{3}{|c|}{ Qualification Average (\%) } & 97.9 \\
\hline & \multicolumn{3}{|c|}{ Qualification Average } & Very high \\
\hline
\end{tabular}

Based on Table 3 there are three aspects assessed by the material expert's validator. These three aspects include the booklet cover, introduction, and subject matter. Here's a further explanation of each aspect. The first aspect, booklet cover. There are three indicators in this aspect. The overall indicator in this aspect scored four. The overall percentage on this aspect is $100 \%$ and included in the category of eligibility is very high. The booklet cover has been prepared following the content and is suitable for use. The second aspect, introduction. In this aspect, there are twelve indicators. All indicators get a score of four with a percentage of $100 \%$ with a very high feasibility category. The introduction has been confirmed to the content and is very appropriate regarding material conformity. The third aspect, the subject matter. In this aspect, there are 18 indicators. Three indicators on this aspect scored 3 and fifteen indicators earned a score of 4 . The overall percentage in this aspect was $95.8 \%$ with a very high feasibility category. The result of booklet SRGF validity by materials expert, it is got the percentage of $97.9 \%$ with the properness category very high. It means that the materials of the SRGF booklet developed are very proper to be used.

\section{c. The Result of Practitioner Field Validity}

The result of the validity SRGF booklet by practitioner field can be seen in Table 4.

Tabel 4. The Result of Practitioner Field Validity

\begin{tabular}{lcccc}
\hline No & Rated Aspect & $\begin{array}{c}\text { Number } \\
\text { of } \\
\text { Aspects }\end{array}$ & $\begin{array}{l}\text { Maximum } \\
\text { Score }\end{array}$ & $\begin{array}{c}\text { Obtained } \\
\text { Score }\end{array}$ \\
\hline 1. & $\begin{array}{c}\text { Qualification } \\
\text { of the content } \\
\text { Qualification } \\
\text { of the presenter } \\
\text { Qualification } \\
\text { of the delivery } \\
\text { The }\end{array}$ & 4 & 16 & $14(87.5 \%)$ \\
3. & 7 & 24 & $13(81.25 \%)$ \\
characteristic \\
of the SRGF \\
program that \\
appears in the \\
booklet
\end{tabular}

Based on Table 4 there are four aspects assessed by environmental practitioner validators. These four aspects include content feasibility, presentation feasibility, and eligibility of delivery, and characteristics of SRFG programs that appear in the booklet. Here's a further explanation of each 
aspect. The first aspect, the content feasibility. In this aspect, there are four indicators. Two indicators in this aspect scored three, and two other indicators scored four. The overall percentage in this aspect is $87.5 \%$ and included in the high feasibility category. Concerning material that became the main content, booklet worthy to be used by the community. The second aspect, the eligibility of the presenter. In this aspect, there are four indicators. Three indicators scored three and one indicators scored four. The overall percentage in this aspect is $81.25 \%$ with high feasibility categories. Booklets are easy to understand concerning presentation. The third aspect, eligibility of delivery. In this aspect, there are six indicators. Four indicators on this aspect scored 3 and two indicators earned a score of 4 . The overall percentage on this aspect was $83 \%$ with high feasibility categories. The language used in the booklet is straightforward and easy to understand. The fourth aspect, the characteristics of the
SRGF program that appears in the booklet. In this aspect there are seven indicators. five indicators on this aspect scored 3, and two indicators earned a score of 4 . The overall percentage on this aspect was $82.1 \%$ with high feasibility categories. The result of booklet SRGF validity by the practitioner field, it is got the percentage of $83.3 \%$ with the properness category high. It means that in the overall side the booklet developed can be used to be implemented.

\section{The Result of the Booklet Practicality Measurement}

This is the last step in developing step. In this step, a preliminary trial with the small-scale trial field is held to know the practicality and legibility of the SRGF booklet that has been revised before and also to get the feedback about the product. Ten aspects are rated by people to know the practicality of the booklet. The result of the practicality measurement by the people can be seen in Table 5 .

Table 5. The Result of the Booklet Practicality Measurement

\begin{tabular}{cccccc}
\hline $\begin{array}{c}\text { Number of } \\
\text { Respondents }\end{array}$ & $\begin{array}{c}\text { Number of } \\
\text { Aspects }\end{array}$ & $\begin{array}{c}\text { Maximum } \\
\text { Score }\end{array}$ & $\begin{array}{c}\text { Obtained } \\
\text { Score }\end{array}$ & Percentage & Category \\
\hline Society -1 & 10 & 40 & 33 & 82,5 & High \\
\hline Society -2 & 10 & 40 & 36 & 90 & Very High \\
\hline Society -3 & 10 & 40 & 31 & 77,5 & High \\
\hline Society -4 & 10 & 40 & 38 & 95 & Very High \\
\hline Society -5 & 10 & 40 & 36 & 90 & Very High \\
\hline Society -6 & 10 & 40 & 34 & 85 & High \\
\hline Society -7 & 10 & 40 & 31 & 77,5 & High \\
\hline Society -8 & 10 & 40 & 29 & 72,5 & High \\
\hline Society -9 & 10 & 40 & 30 & 75 & High \\
\hline Society -10 & 10 & 40 & 38 & 95 & Very High \\
\hline Society -11 & 10 & 40 & 39 & 97,5 & Very High \\
\hline Society -12 & 10 & 40 & 35 & 87,5 & Very High \\
\hline Society -13 & 10 & 40 & 34 & 85 & High \\
\hline Society -14 & 10 & 40 & 34 & 85 & High \\
\hline Society -15 & 10 & 40 & 35 & 87,5 & Very High \\
\hline Average & & $\mathbf{4 0}$ & $\mathbf{3 4 , 2}$ & $\mathbf{8 5 , 5}$ & \\
\hline
\end{tabular}

Based on Table 5 the result of the practicality measurement by the people on the booklet in the small-scale trial, it is got the percentage of $85.5 \%$, with the category high. It means that according to people the whole SRGF booklet developed can be used as counseling media. Testing the practicality of the use of booklets on the community conducted on fifteen community groups. This test is done by giving a questionnaire to each group with ten indicators in each questionnaire. From the total group test, the percentage 85,5 percent with high feasibility category was obtained. This result is a recapitulation of eight groups with a high percentage of feasibility and seven groups with a very high percentage of eligibility. From this test, it is known that the booklets developed are practical and can be implemented in broader society.

\section{CONCLUSION}

Booklet about Sustainable Reserve Food Garden concept (SRFG) which developed pertained valid and practical so that can be implemented further to society.

\section{ACKNOWLEDGMENT}

Product development booklet SRFG that generated the need to be followed up by further tests to determine the level of effectiveness of the booklet SRFG. 


\section{REFERENCES}

[1] Badan penelitian dan pengembangan pertanian, "Kawasan Rumah Pangan Lestari Dan Perkembangan Di Provinsi Kepulauan Bangka Belitung" (Balai Pengkajian Teknologi Pertanian, Bangka Belitung) 2012, pp. 3-5.

[2] M. Ariani, Hermanto, G. S. Hardono, Sugiarto and Wahyudi, "Kajian Strategi Pengembangan Diversifikasi Pangan Lokal" (Pusat Penelitian Sosial Ekonomi pertanian. Badan penelitian dan pengembangan pertanian. Departemen pertanian, Bogor), 2013, pp. 25-31.

[3] T. Rohadi, "Mewujudkan Visi , Misi dan Program Aksi Pemerintahan Baru Bidang Lingkungan Hidup," Jurnal Lingkar Widyaiswara, edited by R. Suyatna et al. (Ikatan Widyaiswara Indonesia, Banten), vol. 1 no.4, pp. 10-20, 2014

[4] H. P. Saliem, E. M. Lokollo, M. Ariani, T. B. Purwantini and Y.Marissa, “Analisis Ketahanan Pangan tingkat rumah tangga dan regional," Laporan hasil penelitian (Pusat Penelitian Sosial Ekonomi pertanian, Badan penelitian dan pengembangan pertanian, Departemen pertanian, Jakarta), 2001, pp. 1-6.

[5] Organization for Economic Cooperation \& Development (OECD), "Kebijakan-kebijakan dalam bidang Pertanian: Pemantauan dan Evaluasi 2013," OECD publishing, 2013, pp. 1-11.

[6] R. Prabowo, "Kebijakan Pemerintah Dalam Mewujudkan Ketahanan Pangan Di Indonesia," edited by R. Prabowo and S. Chan (Fakultas Pertanian Universitas Wahid Hasyim, Semarang, Mediargo Jurnal Ilmuilmu Pertanian, vol.6 no.2, pp. 62-73, 2010.

[7] G. S. Hardono, "Strategi Pengembangan Diversifikasi Pangan Lokal,", edited by A. Suryana et al. (Pusat Sosial Ekonomi dan Kebijakan Pertanian, Bogor), Jurnal Analisis Kebijakan Pertanian, vol. 12 no. 1, pp. 1-17, 2014.

[8] P. Simatupang, Kebijakan dan strategi pemantapan ketahanan pangan wilayah (Balai pengkajian teknologi pertanian NTB, Mataram), 2006 pp. 34-38.

[9] O. O. Adekunle, "The Role of Home Gardens in Household Food Security in Eastern Cape: A Case Study of Three Villages in Nkonkobe Municipality," Journal of Agricultural Science, edited by T. A Omokanye et al. (Canadian Center of Science and Education, Canada, vol. 5, no.10, pp. 67-76, 2013.

[10]Badan Ketahanan Pangan, Pedoman Ketahanan Pangan Tahun 2016 (Badan Ketahanan Pangan Kementrian pertanian, Jakarta), 2016, pp. 1217.

[11]T.S. Aji and M. Sholihah, "Dampak Program Kawasan Rumah Pangan Lestari (KRPL) terhadap Pengeluaran Konsumsi Rumah Tangga (Studi Kasus di Desa Pucangsari Kecamatan Purwodadi Kabupaten Pasuruan)," Jurnal agromix, Vol. 11 No. 4, pp. 1-10, 2014.

[12]Balai Besar Pengkajian dan Pengembangan Teknologi Pertanian (BBP2TP), Petunjuk Pelaksanaan Pengembangan Model Kawasan rumah Pangan Lestari (Balai Besar Pengkajian dan Pengembangan Teknologi Pertanian, Bogor), 2011, pp.6-8

[13]N. P A. Putri, N. Aini and Y. B. S. Heddy, "Evaluasi Keberlanjutan Kawasan Rumah Pangan Lestari (KRPL) di Desa Girimoyo, Kecamatan Karangploso, Malang," Jurnal Produksi Tanaman, edited by N. Barunawati et al., Malang, vol. 3 no. 4, pp. 1-4, 2015

[14] T. B. Purwantini, Saptana and S. Suharyono, "Program Kawasan Rumah Pangan Lestari (KRPL) Di Kabupaten Pacitan: Analisis Dampak dan Antisipasi Ke Depan," Jurnal Analisis Kebijakan Pertanian, edited by A. Suryana et al. (Pusat Sosial Ekonomi dan Kebijakan Pertanian, Bogor), vol. 10 no. 3 , pp. 239-256, 2014

[15]Ferdiana, M. H. I. AL-Muhdar and Suhadi, "Pengembangan Booklet Program Kawasan Rumah Pangan Lestari dan Pengaruhnya Terhadap Pengetahuan Lingkungan Masyarakat Di Kota Malang," Jurnal Pendidikan, edited by I N. S. Degeng (Pascasarjana Universitas Negeri Malang, Malang), vol. 1 no. 7, pp. 1261-1264, 2016.

[16]B. S. Wahyudi, M. H. I. AL-Muhdar and Sueb, "Pengembangan Video Program Kawasan Rumah Pangan Lestari (KRPL) Serta Pengaruhnya Terhadap Motivasi Masyarakat Kota Malang," Jurnal Pendidikan, edited by I N. S. Degeng (Pascasarjana Universitas Negeri Malang, Malang), vol. 1 no.7, pp. 1242-1251, 2016.

[17]B. Timutiasari, M. H. I. AL-Muhdar and Suhadi, Pembelajaran Berbasis Proyek Berbantuan Modul Program Krpl Untuk Mengembangkan Sikap Peduli Lingkungan dan Keterampilan Proses Sains Siswa SD Islam Moh. Hatta Malang," Jurnal Pendidikan, edited by I N. S. Degeng (Pascasarjana Universitas Negeri Malang, Malang), vol. 1 no.6, pp 1185-1190, 2016.
[18] V. C. P. Wulandari, M. H. I. AL.Muhdar, Suhadi, Susilowati and E. Budiningsih, Pengembangan Komik Sebagai Media Pembelajaran Program Kawasan Rumah Pangan Lestari (KRPL), Proceeding in Seminar Nasional Pendidikan dan Saintek 2016 (Universitas Surakarta, Solo, pp. 604-609, 2016.

[19] Mardiana, M. H. I.AL-Muhdar and Sueb, "Pengaruh Modul Program KRPL Berbantuan Pembelajaran Berbasis Masalah (PBM) Terhadap Hasil Belajar Kognitif dan Sikap Peduli Lingkungan Siswa Kelas VII SMPN 18 Malang," Jurnal Pendidikan, edited by I N. S. Degeng (Pascasarjana Universitas Negeri Malang, Malang), vol. 1 no. 1, pp. 2534, 2016.

[20]D. Adri, M. H. I. AL.Muhdar, Suhadi, Susilowati and E. Budiningsih, "Program Kawasan Rumah Pangan Lestari (Krpl):Analisis Pengetahuan dan Perilaku Masyarakat," Proceeding in Seminar Nasional ke-3 Biologi, IPA, dan Pembelajarannya, edited by H. Susilo et al. (Fakultas Matematika dan Ilmu Pengetahuan Alam Universitas Negeri Malang, Malang) pp. 46-51, 2016.

[21]M. Subadar,"Analisis Peran Lembaga Terhadap Program KRPL (Kawasan Rumah Pangan Lestari) di Desa Pucungsari Kecamatan Purwodadi Kabupaten Pasuruan," Jurnal Agromix, vol. 4 no. 2, , pp 42 47, 2013.

[22]M. L. Silberman, Active Learning 101 Cara Bealajar Siswa Aktif, Nuansa, Bandung, 2006, pp. 34-38.

[23] Telkom University, Paduan Penulisan dan Hibah buku, Bandung, 2015, pp. 4-6.

[24]Pusat Perbukuan Depdiknas, Pedoman Penilaian Buku Nonteks Pelajaran, Departemen Pendidikan Nasional, Jakarta, 2008, pp. 46-49.

[25]C. M. Hapsari, "Efektifitas Komunikasi Media Booklet "Anak Alami" Sebagai Media Penyampai Pesan Gentle Birthing Service,” Jurnal EKomunikasi, vol. 1 no. 3, pp. 274-288, 2013

[26]K. Mahendra and Sudarmin, "Pengembangan Booklet Etnosains Fotografi Tema Ekosistem Untuk Meningkatkan Hasil Belajar Pada Siswa SMP," Unnes Science Education Journal, vol. 4 no. 2, edited by A. Widiyatmoko et al. (Universitas Negeri Semarang, Semarang, pp. $866-872,2015$

[27]I. Machfoedz and E. Suryani, Pendidikan Kesehatan Bagian dari Promosi Kesehatan, Fitramaya, Yogyakarta, 2005, pp. 123-129.

[28]F. Efendi and Makhfudli, Keperawatan Kesehatan Komunitas: Teori dan Praktik dalam Keperawatan, Salemba, Jakarta, 2009, pp. 67-72.

[29] S. Akbar, Instrumen Perangkat Pembelajaran, PT Remaja Rosdakarya, Bandung, 2015, pp. 32-48. 
